\title{
DID THE SINGLE MARKET CAUSE COMPETITION IN EXCISE TAXES? EVIDENGE FROM EU COUNTRIES*
}

\author{
Ben Lockwood and Giuseppe Migali
}

\begin{abstract}
Tax competition theory predicts that the introduction of the EU Single Market in 1993 should have caused excise tax competition and thus increased strategic interaction in the setting of excise taxes among EU countries. We test this prediction using a panel data set of $12 \mathrm{EU}$ countries over the period 1987-2004. We find that for excise duties on still and sparkling wine, beer and ethyl alcohol, strategic interaction significantly increased after 1993. There is weaker evidence of increased interaction in cigarette taxes, possibly because cigarettes are widely smuggled, giving rise to tax competition even before the Single Market.
\end{abstract}

The Single European Act, which came into force in July 1987, initiated a vast legislative programme involving the adoption of hundreds of directives and regulations, which gradually established the single market amongst EU member states over a period up to the end of 1992. Two of the most important provisions of the single market were: first, to allow individuals to import relatively large quantities of goods purchased abroad, which had previously been subject to the importing country's rate of tax and, second, the abolition of physical border controls, which were replaced by random spot checks.

Before 1 January 1993, all imports by EU residents from other EU countries were essentially subject to destination-based taxation i.e. taxation at the rate of excise and VAT of the country to which the good was imported. ${ }^{1}$ But, since 1 January 1993, all imports by EU residents from other EU countries were subject to origin-based taxation. Specifically, there are no restrictions on such imports, except

(i) that tax must have been paid in the country of purchase of the good and

(ii) that goods are not for resale.

Condition (ii) is enforced by generous upper limits, plus random customs checks at borders. For example, according to the UK Customs and Excise, 'if you bring back large quantities of alcohol or tobacco, a Customs Officer is more likely to ask about the purposes for which you hold the goods. This will most likely be the case if you appear at the airport with more than: 3,200 cigarettes, 400 cigarillos, 200 cigars, $3 \mathrm{~kg}$ of smoking tobacco, 110 litres of beer, 10 litres of spirits, 90 litres of wine, 20 litres of fortified wine i.e.: port or sherry'. The above allowance is more than enough for the annual consumption of the average two-adult household. Moreover, imports in excess of these levels do not automatically trigger fines or prosecution: the levels are indicative only, and the onus is on Customs officials to prove smuggling.

\footnotetext{
* We thank Paul Elhorst, Paulo Parente, two anonymous referees, the editor, the seminar participants at the 2008 RES conference in Warwick, at the 2007 summer school on Tax Competition at Institut d'Economia de Barcelona, for helpful comments and discussions and we are grateful to the Office of Taxation and Customs of the European Commission for useful advice.

${ }^{1}$ A minor qualification is that small quantities of excisable products could be bought at duty-free shops in airports, on boats, etc., without any tax payable. But, the amounts involved are quite small.
} 
These changes in the rules create incentives both for legitimate tax-induced crossborder shopping and for smuggling. There is evidence that both these activities are occurring on a large scale at some borders. For example, the rates of excise duty on alcoholic drinks and tobacco products in the UK are significantly higher than those in most other EU Member States, especially France. The UK tax authority (HMRC, 2002) estimates that 2001/2: $7 \%$ of all cigarettes consumed in the UK were cross-border shopped, and $21 \%$ illegally smuggled, implying a tax revenue loss of £3.6 billion to the UK Treasury, $7 \%$ of all wine consumed in the UK was cross-border shopped and $2 \%$ illegally smuggled, implying a tax revenue loss of over $£ 250$ million, and $1 \%$ of all beer consumed in the UK was cross-border shopped and $4 \%$ smuggled, mostly by 'crosschannel passenger smuggling’, implying a loss of also over $£ 250$ million.

What is less clear is whether these changes, and the subsequent excise revenue losses in high-tax countries, have caused tax competition between EU member states to occur or intensify. Certainly, the theory (Kanbur and Keen, 1993; Lockwood, 1993; Ohsawa, 1999; Nielsen, 2001) suggest that this should happen. As just observed, the Single Market resulted in a switch from destination- to origin-based taxation of cross-border transactions by individuals. These models predict that tax competition only occurs with origin-based taxation. So, the models predict, unambiguously and generally, that we should observe competition in excise taxes between EU countries only after $1993 .^{2}$

It is important to test this prediction, not least because of widespread concern on the part of policy makers, perhaps motivated by the theory, about the single market and tax competition. For example, it is well documented that fear of excise tax competition after the completion of the single market caused the European Commission to push for minimum excise taxes in the late 1980s; these minima were actually introduced in 1993. ${ }^{3}$ This article represents the first attempt, to our knowledge, to do this directly.

Of course, strategic interaction can occur for other reasons e.g. yardstick competition, or common intellectual trends. So, the observable implication of the theory is that strategic interaction between EU countries in the setting of excise taxes should intensify after 1993. How much it intensifies depends on the scale of cross-border shopping and potential revenue losses from high taxes: as the above discussion indicates, these might be quite large. The key idea of the article is that completion of the single market can be interpreted as a kind of 'natural experiment' that allows us to separate the effects of tax competition from other forms of strategic interaction.

We employ a balanced panel data set of 12 EU countries over the period 1987-2004, which has excise taxes on five commodities: still wine, sparking wine, beer, products made from ethyl alcohol, i.e. spirits, and cigarettes. The excise tax data were taken from the European Commission's Excise Duty Tables and Inventory of Taxes. Using this data

\footnotetext{
${ }^{2}$ A possible counter-argument concerns diversion fraud i.e. diversion of goods in bonded warehouses destined for export to the domestic market, where they are illegally sold without payment of excise taxes. This activity has become easier since the advent of the single market. Diversion fraud can only be limited by cutting tax rates and so the incentives to cut rates, independently of what other countries do, may have increased since 1993. This is a force that might actually weaken tax competition since 1993 (we are indebted to a referee for this point).

3 'The prospect of tax-cutting has thus become a principal concern in discussions of indirect tax policy ... Approximation is one obvious response ... the original approximation proposals were replaced by a more pragmatic approach (of) a minimum standard rate of VAT of 15 per cent ... (and) minimum excise rates.' (Keen, 1993, p. 26).
}

(C) The Author(s). Journal compilation (C) Royal Economic Society 2009 
set, we estimate an empirical model where the excise tax in a given country depends linearly on the weighted average of other countries' taxes and a set of control variables. Following the literature, we assume that the weights are contiguity weights; that is, country $i$ reacts to $j$ 's tax only if they have a common border. This is a very plausible assumption to make, as cross-border shopping typically occurs between immediate geographical neighbours. ${ }^{4}$

We test for structural breaks in reaction functions around 1993 in two ways. First, in order to conserve degrees of freedom, given the relatively small size of the sample, we only allow the slope of the tax reaction function to vary before and after 1993, imposing equality on all the other coefficients. We call this specification a tax-specific structural break. Then, we allow for a completely general structural break, estimating the tax reaction functions separately on sub-samples before and after 1993.

For both specifications, we find robust evidence that for all product groups except cigarettes, the degree of strategic interaction has increased since 1993. For the baseline tax-specific structural break model, the slope of the tax reaction function is insignificantly different from zero prior to 1993 for wine, beer or alcohol taxes, but it is always significantly positive after 1993. A 1 euro increase in a tax on one of these product groups by all other countries causes a typical country in the sample to raise its own tax by about $0.2-0.28$ euro. For the general structural break model, the findings are similar. The slope of the tax reaction function is always insignificantly different from zero prior to 1993 for wine, beer or alcohol taxes, but it is always significantly positive after 1993. Moreover, we can always reject the null hypothesis of equality of coefficients in the two regressions.

Thus one could go further and say that for these four products, there is evidence, consistent with the theory, that the single market, by creating incentives for crossborder shopping, caused strategic interaction between countries in the form of tax competition.

The situation for cigarette taxes, is however, rather different. As explained in more detail below, overall, there is much weaker evidence that tax competition intensified with the single market in the case of cigarettes. ${ }^{5}$ One possible explanation for this difference is that, as remarked above, the amount of illegal smuggling relative to crossborder shopping is much larger for cigarettes than it is for the other products. So, it is possible that governments of the countries in our sample took account of how their neighbours were taxing cigarettes even before 1993 for this reason. ${ }^{6}$

In Section 4, we discuss the robustness of our findings to various changes in the empirical specification of the model. We consider the effect of dropping country controls in the general structural break model, because they seem to be imprecisely estimated in the period 1987-2002, due to the small number of observations. Our results are robust to this change. We also experiment with different weighting schemes, and measuring the taxes in national currency, rather than euros.

\footnotetext{
4 The robustness of the results with respect to other weights are tested in Section 4.2.

${ }^{5}$ Specifically, for both model specifications, and for both the specific component of the tax and the total tax, there is evidence of significant strategic interaction prior to 1993.

${ }^{6}$ Smuggling creates incentives for tax competition even if legal transactions are subject to destinationbased taxes, because smugglers have incentives to transport goods illegally to where taxes, and thus prices, are high.

(C) The Author(s). Journal compilation (C) Royal Economic Society 2009
} 
Finally, we also investigate the impact of minimum tax rates, also introduced in 1993, on strategic interaction. Unfortunately, as explained in Section 4.3, the theory does not have any robust predictions about how a minimum tax will affect tax reaction functions. Also, because we split the sample in 1993, we can only consider minimum taxes that change in real terms after 1993. Only two such minima meet this criterion, the minimum taxes on beer and ethyl alcohol. ${ }^{7}$ An increase in both of these minima have a significantly positive effect on the amount of strategic interaction.

The related literature is as follows. First, there is a small empirical literature on spatial interactions in excise taxes in the US (Nelson, 2002; Rork, 2003; Devereux et al., 2007). But in the US, there has been no 'natural experiment' similar to the completion of the single market in the EU in recent times. Within the US, transactions by individuals of excisable commodities that cross state borders are essentially unrestricted, meaning that the origin regime is firmly in place for these kinds of transactions. ${ }^{8}$

There are also a couple of cross-country empirical studies of strategic interaction in commodity taxes (Egger et al. 2005; Evers et al. 2004). Egger et al. (2005) test some of the predictions of Ohsawa's theoretical model of commodity tax competition on commodity tax data for a panel of 22 OECD countries. But, unlike our study, they use an aggregate indicator of commodity taxation taken from national accounts data, which, relative to our article, obviously has the disadvantage that it does not measure the setting of individual tax instruments by governments very precisely.

The article by Evers et al. (2004), in contrast, studies strategic interaction in the setting of diesel excises in EU countries, plus Norway and Switzerland, and so is closest to our article. But, almost by definition, the treatment of imports of fuel in the tank of a vehicle must be on an origin basis ${ }^{9}$ and so completion of the single market has no predicted effect on the setting of this excise, except possibly through the introduction of a minimum EU excise; the latter effect is the focus of Evers et al. (2004).

Finally, Crawford et al. (1999) study a related issue; whether the elasticity of demand for beer, wines and spirits has increased in the UK since the advent of the single market. They reject the hypothesis that elasticities have increased, which is somewhat surprising given the very large scale of cross-border shopping for these goods in France. In any case, this does not directly contradict our findings, as tax competition could be driven by the belief on the part of governments that elasticity of the domestic tax base has increased, whether or not it has in reality.

The rest of the article is structured as follows. In Section 1, we explain our econometric method and estimation procedure. Section 2 describes the data, Section 3 the results and Section 4 some robustness checks. Section 5 provides concluding comments.

\footnotetext{
7 The minimum tax on wine (still or sparkling) is zero, and on cigarettes, the minimum is expressed as a percentage of the retail price, which has not changed since its introduction.

${ }^{8}$ The borderline of legality in the case of cigarettes is provided by the Contraband Cigarette Act of 1978, which prohibits single shipments, sale or purchase of more than 60,000 cigarettes not bearing the tax stamp of the state in which they are found.

${ }^{9}$ That is, even with border controls, customs officials have no way of knowing where the fuel in the tank of a vehicle has been bought.

(C) The Author(s). Journal compilation (C) Royal Economic Society 2009
} 


\section{The Econometric Model}

In the theoretical model first presented by Kanbur and Keen (1993) and developed by Ohsawa (1999) and Nielsen (2001) amongst others, origin-based commodity taxation generates positively sloped tax reaction functions between a set of countries. ${ }^{10}$ That is, under the assumptions made in those papers, in country $i=1, \ldots, n$, the excise tax, $\tau_{i}$, is an increasing, piecewise linear, function of the tax rate in the other countries, $\tau_{j}, j \neq i$. Moreover, under realistic assumptions, ${ }^{11}$ the response of $\tau_{i}$ to $\tau_{j}$ will be non-zero only if $i$ and $j$ are contiguous, i.e. share a common border. Finally, this response will depend on the length of the border between $i$ and $j$ and also on the population sizes in the two countries (Ohsawa, 1999; Devereux et al., 2007).

Our empirical specification is therefore the following:

$$
\tau_{i t}=f_{i}+\sum_{j \neq i} \alpha_{i j} \tau_{j t}+\boldsymbol{\delta}^{\prime} \mathbf{z}_{i t}+\epsilon_{i t}
$$

where $i=1, \ldots, n$ denotes a country, $t=1, \ldots, T$ a time-period, $f_{i}$ a country fixed effect, $\mathbf{z}_{i t}$ a $k \times 1$ vector of relevant characteristics of country $i$ at time $t, \boldsymbol{\delta}$ a $k \times 1$ vector of coefficients and, finally, $\alpha_{i j}$ are coefficients measuring how $\tau_{i}$ responds to $\tau_{j}$. However, this cannot be estimated as it stands, as there are too many parameters $\alpha_{i j}$ to be estimated. The usual approach is define $\alpha_{i j}=\beta \omega_{i j}$ and thus to modify (1) as:

$$
\tau_{i t}=f_{i}+\beta \tau_{-i, t}+\boldsymbol{\delta}^{\prime} \mathbf{z}_{i t}+\epsilon_{i t}, \tau_{-i, t}=\sum_{j \neq i} \omega_{i j} \tau_{j t}
$$

where the $\omega_{i j}$ are exogenously chosen weights that aggregate the tax rates in other countries into a single variable $\tau_{-i, t}$, which has coefficient $\beta$. The $\omega_{i j}$ are usually normalised so that $\sum_{j \neq i} \omega_{i j}=1$. This is a widely used procedure and there is considerable discussion of the appropriate weights in the literature, e.g., Brueckner (2003).

Our key theoretical hypothesis is that $\beta$ is higher when the Single Market regime is in place. In fact, if only tax competition and no other form of strategic interaction is present, we expect $\beta=0$ before 1993. We test for this dependence in two ways. First, we allow for a change only in the reaction function slope coefficient $\beta$ after 1993, assuming that all other coefficients remain unchanged. That is, we estimate

$$
\tau_{i t}=f_{i}+\beta \tau_{-i, t}+\gamma\left(D_{t} \times \tau_{-i, t}\right)+\boldsymbol{\delta}^{\prime} \mathbf{z}_{i t}+\epsilon_{i t}
$$

where $D_{t}=1$ if $t \geq 1993$ and $D_{t}=0$ otherwise. The theory thus predicts that $\gamma>0$. This has the advantage of being a relatively parsimonious specification, with only $\beta, \gamma$ and coefficients on five exogenous covariates to be estimated. ${ }^{12}$ This is important because of the relatively small size of the panel; we only have 204 observations. We call this the tax-specific structural break specification.

\footnotetext{
${ }^{10}$ Piecewise linear reaction functions are generated by the assumption that the population is uniformly distributed within each country. If the density of the population is the same within each country, then the reaction functions are just linear.

${ }^{11}$ That is, that prices are such that consumers do not wish to drive though a third country to buy in a lowtax country.

12 We estimate (3) using the within transformation (Wooldridge, 2002), so the time demeaning of (3) removes the country-specific effect $f_{i}$.
}

(C) The Author(s). Journal compilation (C) Royal Economic Society 2009 
We test the robustness of the tax-specific structural break specification by allowing for a more general structural break; that is, by estimating (2) separately on sub-samples 1987-92 and 1993-2004. Let the estimates of $\beta$ on the earlier and later sub-samples be $\beta_{1}, \beta_{2}$ respectively. So, our basic hypothesis is that $\beta_{2}>\beta_{1}$. Note also that with this specification we effectively allow the intercept of the reaction functions (2) to shift after 1993. We call this the general structural break specification. This specification is more demanding of the data, as then in the earlier period, six parameters $\beta, \boldsymbol{\delta}$ are to be estimated from only 60 observations.

The system (2) is known as a spatial autoregressive model (SAR). OLS estimation of a SAR model is inappropriate, because the right-hand side variables $\tau_{j t}, j \neq i$ are endogenous. We estimate this system by instrumental variables. In the case of the general structural break model, at the first stage, the endogenous variable $\tau_{-i, t}$ is instrumented by the weighted averages of the controls i.e. $z_{-i, t}^{c}=\sum_{j \neq i} \omega_{i j} z_{j t}^{c}$, for control $c=1, . . k$. In the case of the tax-specific structural break model, there are two endogenous variables, $\tau_{-i, t}$ and $D_{t} \times \tau_{-i, t}$, and these are instrumented by $z_{-i, t}^{c}$, and $D_{t} \times z_{-i, t}^{c}$. So, our maintained hypothesis is that in country, the controls are exogenous to the setting of excise taxes on tobacco and alcohol products; given our list of controls in Table 1 below, this seems reasonable.

Finally, we turn to the specification of the weighting matrix. Following the theoretical literature and several empirical studies, our baseline weighting matrix uses contiguity weights. These weights capture the idea that with cross-border shopping, tax bases are typically mobile only between geographically neighbouring countries and so governments are likely to react only to what their geographical neighbours do. Specifically, we define contiguity weights as:

Table 1

Descriptive Statistics

\begin{tabular}{|c|c|c|c|c|}
\hline & \multirow[b]{2}{*}{ Mean } & \multicolumn{3}{|c|}{ Standard deviation } \\
\hline & & Overall & Within & Between \\
\hline \multicolumn{5}{|l|}{ Tax variables } \\
\hline Still wine* & 49.222 & 77.858 & 18.094 & 78.899 \\
\hline Sparkling wine* & 107.711 & 139.652 & 29.825 & 142.147 \\
\hline Beer $^{\dagger}$ & 2.095 & 2.207 & 0.539 & 2.230 \\
\hline Ethyl alcohol $l^{+}$ & 1299.449 & 814.965 & 375.130 & 753.811 \\
\hline Cigarettes spec ${ }^{\S}$ & 29.574 & 34.595 & 16.355 & 31.763 \\
\hline Cigarettes tot & 64.566 & 11.195 & 9.754 & 5.724 \\
\hline \multicolumn{5}{|l|}{ Controls } \\
\hline Poptot & 292.126 & 268.515 & 6.899 & 279.674 \\
\hline Govcons & 19.864 & 3.295 & 0.991 & 3.274 \\
\hline Govright & 0.436 & 0.497 & 0.461 & 0.191 \\
\hline Govleft & 0.274 & 0.447 & 0.326 & 0.318 \\
\hline
\end{tabular}

\footnotetext{
*euro per h1 of product not exceeding $12 \%$ of alcohol.

†euro per h1/degree Plato, alcoholic strength by volume exceeding $0.5 \%$.

teuro per h1 of pure alcohol.

§euro per 1000 cigarettes.

$\Phi \%$ retail price.

Euro converted from national currency, before 01/01/1999 ECU.
} 


$$
\omega_{i j}= \begin{cases}1 / n_{i} & \text { if } j \in N_{i} \\ 0 & \text { if } j \notin N_{i}\end{cases}
$$

where $N_{i}$ is the set of states that border state $i$, and $n_{i}=\# N_{i}$. This assigns equal weight to all countries on the border of country $i$, and weight zero to the other countries. The matrix is normalised to have rows summing to one.

One problem in implementing (4) is that it is difficult to define 'neighbours' when a country is an island, or part of an island, or has no direct EU neighbours. These problems arise for three of the eight countries in our data-set: UK, Ireland and Greece. A strict imposition of contiguity weights for the UK, for example, would give only Ireland as the neighbour for the UK and vice versa. This is inaccurate, because it does not account for the considerable tax-induced cross-border shopping between the UK and France. Our solution is to say that if $i$ is an island, a positive contiguity weight was given to country $j$ when $j$ could be directly reached from country $i$ by crossing only over water, i.e. without passing through a third country. ${ }^{13}$ In Section 4.2, we consider the robustness of our results to alternative weighting schemes.

\section{Data}

We construct a balanced panel of data from 12 EU countries over 17 years, 1987 and 1989-2004 inclusive. We consider only the countries which were members of the EU in 1987, excluding those that joined the EU later on. Data are not available for the year 1988, so there are 204 observations. Data on excises are based on the Excise Duty Table issued by the European Commission, cross-checked against the available issues of the Inventory of Taxes (only available for 1994, 1999, 2002). In the case of a discrepancies, which were not many, we took the data from the Inventory of Taxes as being authoritative, as these data are directly supplied by the member countries.

We study taxes on five kinds of products: still wine, sparkling wine, beer, cigarettes and ethyl alcohol, the last being effectively an excise tax on spirits, such as whisky, brandy etc. ${ }^{14}$ All of these products, except for cigarettes, are only subject to a specific excise tax, i.e. levied per unit of physical quantity. Where there are several rates of tax, e.g., standard and reduced rates, we use only the standard rates. The physical units in which the goods are measured are indicated in Table 1.

In the case of cigarettes, all countries also levy an ad valorem excise tax. Moreover, depending on the country, either the specific or ad valorem component of the tax can be the more important one and so we cannot safely ignore either. We do not have data separately on the retail price of cigarettes, so we are constrained by data in the Excise Duty Tables. These report both the specific tax and the total tax (specific, ad valorem and VAT) as a percentage of the retail price. We use both these tax measures.

\footnotetext{
${ }^{13}$ For example, the UK has only Ireland as a land neighbour but we assume also that Belgium, France and Netherlands are neighbours, as they can be directly reached crossing the Channel. For Ireland, due to its distance from continental Europe, we assume the UK as the only neighbour. Greece does not have any EU land neighbour and so Italy is its only neighbour by this criterion.

${ }^{14}$ In the case of beer, there were two kinds of physical unit used in the Excise Duty Tables: degree Plato and degree of alcohol by volume. According to Directive 92/84/EEC it has been accepted that a tax of 0.748 euro Plato is equal to a tax of 1.87 euro alcohol by volume so we applied this conversion factor.
}

(C) The Author(s). Journal compilation (C) Royal Economic Society 2009 
In Figures A.1-A.5 in the Appendix, we report for each of the five goods the time series plot of the tax rates in national currency, unadjusted for inflation. Some general features can be identified. First, as might be expected, countries generally adjust their taxes upwards, in response to general price inflation. Second, there are some exceptions, associated with the start of the single market in 1993. For example, both Denmark and Luxembourg cut their tax on wine (still and sparkling) by large amounts in 1992, in the case of Luxembourg to zero. Again, Denmark cut its tax on beer, and Germany and Luxembourg raised their tax on beer, both by large amounts, in 1992.

When we run the regressions, we make two changes to the dependent variable. First, we adjust for inflation by dividing through by the RPI for the relevant country, with 2000 as the base year, because rational governments will be concerned with the real, rather than nominal, value of the taxes they set. Perhaps for this reason, we did not find any evidence of strategic interaction when we used nominal taxes. Second, we find that our regressions work a little better when the dependent variable is converted to euros, ${ }^{15}$ possibly because countries are comparing their own taxes to others in different national currencies and can only do so in a common currency. ${ }^{16}$

Table 1 gives some basic decomposition of the variance of both taxes and covariates between country and within-country components. The taxes are in real terms, expressed in euros. Note that while most of the variation is between countries, there is some variation in taxes over time. ${ }^{17}$

Finally, in estimating the determinants of the taxes, we need to control for other factors. We use a parsimonious set of controls that can be found in most of the existing empirical literature on tax competition. First, we have the basic variables of GDP per capita in local currency units and total population in hundreds of thousands of inhabitants. We expect total population to increase the level of tax, as it is a robust prediction of the theory that larger countries set higher taxes in the origin regime, because they have a larger domestic tax base. (The GDP per capita variable is not reported in Table 1, as it is not comparable across countries.) We also include government final consumption expenditure as a percentage of GDP as an indicator of demand for tax revenue. All of these variables are taken from World Bank WDI.

We add two political 0-1 dummy variables for the ideological orientation of governments. We used the Schmidt Index, ${ }^{18}$ included in the Comparative Political Data Set 1960-2004 (Armingeon et al., 2006), to define a dummy for right-wing cabinets, a dummy for stand-off between left and right cabinets, and a dummy for left-wing cabinets. The second dummy is used as the reference category in the estimation. The descriptive statistics for the controls are also given in Table 1.

15 Before 1999, we converted national currencies to ECU using the exchange rates provided in the Excise Duty Tables.

${ }^{16}$ We tried the same regressions using the tax variables in real national currency. The results are broadly similar and are not reported here to save space. The results are in Table 9 of Lockwood and Migali (2008).

17 Due to the way that Stata calculates the decomposition, the two components add up to more than the total variance.

18 This is an index created by Schmidt (1996), which gives different weights according to the cabinet composition. Schmidt-Index: (1) hegemony of right-wing parties $\left(\right.$ gov $\left._{\text {left }}=0\right)$, (2) dominance of right-wing (and centre) parties $\left(\right.$ gov left $\left._{\text {l }}<33.3\right)$, (3) stand-off between left and right $\left(33.3<\right.$ gov left $\left._{l}<66.6\right)$, (4) dominance of social-democratic and other left parties $\left(\operatorname{gov}_{\text {left }}>66.6\right)$, (5) hegemony of social-democratic and other left parties $\left(\right.$ gov $\left._{\text {left }}=100\right)$.

(C) The Author(s). Journal compilation (C) Royal Economic Society 2009 


\section{Results}

The results are given by commodity in Tables $2-4$. All have the same format. Each Table gives the results for a pair of taxes. The top panel gives regression coefficients. In columns 1 and 4, the estimate of the baseline tax-specific structural break model (3) is reported. The key coefficient of interest is the coefficient on $D \times \tau_{-i}$, i.e. just $\gamma$ in (3). In columns 2 and 3, and in columns 5 and 6 , the estimate of the general structural break model is reported. For example, looking at columns 2 and 3 of Table 2, we see that these report estimates of (2) for the specific tax on still wine for each of the two sub-periods 1987-92, and 1993-2004 are separately.

The middle panel gives the number of observations, and two tests. The first is an F-test for joint significance of the controls. The second is a test for the equality of coefficients across the two sub-periods in the general structural break model. ${ }^{19}$

In the bottom panel of the Table, the following diagnostic statistics are also reported. First, Pagan and Hall's (1983) test is a test of heteroscedasticity for instrumental variables (IV) estimation. This statistic is distributed as chi-squared under the null of no heteroscedasticity and under the maintained hypothesis that the error of the regression is normally distributed. When we find heteroscedasticity we report the corrected standard errors using a robust variance estimator.

Second, the $\mathrm{F}_{I V}$ in the first stage of the estimation tests the null hypothesis that the instruments are not correlated with the endogenous variable. A rejection means that there is such a correlation. We can reject the null in all but three cases (the shorter sample period 1987-92 for wine and beer). Note that as there are two endogenous variables in the tax-specific structural break, there are two such tests, denoted $\mathrm{F}_{I V_{1}}, F_{I V_{2}}$. In the general structural break model, only $\mathrm{F}_{I V_{1}}$ applies. Under the null hypothesis that instruments are not correlated with the endogenous variable, $\mathrm{F}_{I V_{1}}$ and $\mathrm{F}_{I V_{2}}$ follow an $\mathrm{F}$ distribution. ${ }^{20}$

Third, the Anderson canonical correlations likelihood-ratio tests whether the equation is identified. ${ }^{21}$ The statistic provides a measure of instrument relevance, and rejection of the null indicates that the model is identified.

Fourth, the Hansen-Sargan test is a test of overidentifying restrictions. The joint null hypothesis is that the instruments are valid instruments, i.e., uncorrelated with the error term. Under the null, the test statistic is distributed as chi-squared in the number of overidentifying restrictions. A rejection casts doubt on the validity of the instruments. Looking across all regressions in Tables $2-4$, this test is passed at $5 \%$ in all but one case (the tax-specific structural break model in the case of sparkling wine).

19 The test statistic is $\left(R S S-R S S_{1}-R S S_{2}\right) / 6 /\left(R S S_{1}+R S S_{2}\right) /(204 \times 17-12)$, where $R S S, R S S_{1}, R_{S S}$ are the residual sums of squares of the regressions on the full sub-sample and the first and second sub-samples respectively. Under the null hypothesis of equality of all coefficients, this has a distribution $\mathrm{F}(K, N T-2 K)$.

${ }^{20}$ The degree of freedom of these tests depend on the set of instruments used and, in our estimation, we do not always use the full set but the combination that passes the identification tests. In general, the $\mathrm{F}$ test is distributed as $\mathrm{F}(L, N-K)$ where $L=$ number of instruments, $N=$ sample size (reduced by the number of fixed effects, 12 in our case), $K=$ number of regressors including the instruments.

21 The null hypothesis of the test is that the matrix of reduced form coefficients has rank $=K-1$, where $K=$ number of regressors, i.e, that the equation is underidentified. Under the null of underidentification, the statistic is distributed as chi-squared with degrees of freedom $=(L-K+1)$, where $L=$ number of instruments (included + excluded).

(C) The Author(s). Journal compilation (C) Royal Economic Society 2009 
Table 2

Estimates for Wine Taxes

\begin{tabular}{|c|c|c|c|c|c|c|}
\hline & \multicolumn{3}{|c|}{ Still wine } & \multicolumn{3}{|c|}{ Sparkling wine } \\
\hline & & 1987-92 & 1993-2004 & & 1987-92 & 1993-2004 \\
\hline$\tau_{-i}$ & $\begin{array}{c}-0.165 \\
(0.318)\end{array}$ & $\begin{array}{c}-0.521 \\
(1.458)\end{array}$ & $\begin{array}{l}0.423 * * * \\
(0.151)\end{array}$ & $\begin{array}{c}-0.044 \\
(0.417)\end{array}$ & $\begin{array}{c}-0.704 \\
(2.467)\end{array}$ & $\begin{array}{l}1.215 * * * \\
(0.323)\end{array}$ \\
\hline$D \times \tau_{-i}$ & $\begin{array}{l}0.280 * * \\
(0.131)\end{array}$ & & & $\begin{array}{l}0.206^{* *} \\
(0.095)\end{array}$ & & \\
\hline Total population & $\begin{array}{l}0.461 * * \\
(0.228)\end{array}$ & $\begin{array}{c}0.669 \\
(0.588)\end{array}$ & $\begin{array}{c}0.440^{*} \\
(0.258)\end{array}$ & $\begin{array}{l}0.961 * * * \\
(0.312)\end{array}$ & $\begin{array}{c}1.839 \\
(1.362)\end{array}$ & $\begin{array}{r}-0.023 \\
(0.226)\end{array}$ \\
\hline$g d p p c$ & $\begin{array}{c}-0.037 \\
(0.023)\end{array}$ & $\begin{array}{c}-0.043 \\
(0.174)\end{array}$ & $\begin{array}{c}0.005 \\
(0.015)\end{array}$ & $\begin{array}{c}-0.137 * * \\
(0.057)\end{array}$ & $\begin{array}{c}-0.103 \\
(1.021)\end{array}$ & $\begin{array}{r}-0.061 \\
(0.048)\end{array}$ \\
\hline govcons & $\begin{array}{c}-2.066^{*} \\
(1.206)\end{array}$ & $\begin{array}{c}0.491 \\
(2.751)\end{array}$ & $\begin{array}{r}-0.566 \\
(1.100)\end{array}$ & $\begin{array}{c}-4.463 * \\
(2.467)\end{array}$ & $\begin{array}{c}-0.504 \\
(5.592)\end{array}$ & $\begin{array}{c}4.509 \\
(3.161)\end{array}$ \\
\hline govright & $\begin{array}{c}-3.048 \\
(3.320)\end{array}$ & $\begin{array}{l}7.046 \\
(5.944)\end{array}$ & $\begin{array}{c}-1.413 \\
(3.433)\end{array}$ & $\begin{array}{c}-4.861 \\
(6.075)\end{array}$ & $\begin{array}{c}15.431 \\
(13.587)\end{array}$ & $\begin{array}{c}7.076 \\
(8.238)\end{array}$ \\
\hline govleft & $\begin{array}{c}-3.892 \\
(4.128)\end{array}$ & $\begin{array}{c}7.956 \\
(6.911)\end{array}$ & $\begin{array}{c}-2.330 \\
(4.430)\end{array}$ & $\begin{array}{r}-6.457 \\
(6.279)\end{array}$ & $\begin{array}{c}12.950 \\
(16.250)\end{array}$ & $\begin{array}{c}4.842 \\
(8.095)\end{array}$ \\
\hline$N$ & 204 & 60 & 144 & 204 & 60 & 144 \\
\hline F-test & $\begin{array}{c}4.010 \\
(0.000)\end{array}$ & $\begin{array}{c}0.515 \\
(0.794)\end{array}$ & $\begin{array}{c}3.124 \\
(0.007)\end{array}$ & $\begin{array}{c}7.136 \\
(0.000)\end{array}$ & $\begin{array}{c}0.917 \\
(0.493)\end{array}$ & $\begin{array}{c}4.319 \\
(0.001)\end{array}$ \\
\hline Str. break & \multicolumn{4}{|c|}{ Reject $\mathrm{H}_{0}$} & \multicolumn{2}{|c|}{ Reject $\mathrm{H}_{0}$} \\
\hline Pagan-H & $\begin{array}{l}80.656 \\
(0.000)\end{array}$ & $\begin{array}{c}7.693 \\
(0.989)\end{array}$ & $\begin{array}{l}72.984 \\
(0.000)\end{array}$ & $\begin{array}{l}78.595 \\
(0.000)\end{array}$ & $\begin{array}{c}6.212 \\
(0.997)\end{array}$ & $\begin{array}{l}39.825 \\
(0.003)\end{array}$ \\
\hline $\mathrm{F}_{I V_{1}}$ & $\begin{array}{c}4.625 \\
(0.000)\end{array}$ & $\begin{array}{l}1.120 \\
(0.352)\end{array}$ & $\begin{array}{c}3.774 \\
(0.012)\end{array}$ & $\begin{array}{c}7.454 \\
(0.000)\end{array}$ & $\begin{array}{c}0.262 \\
(0.852)\end{array}$ & $\begin{array}{c}4.823 \\
(0.003)\end{array}$ \\
\hline $\mathrm{F}_{I V_{2}}$ & $\begin{array}{c}9.017 \\
(0.000)\end{array}$ & & & $\begin{array}{l}18.508 \\
(0.000)\end{array}$ & & \\
\hline Anderson & $\begin{array}{l}26.146 \\
(0.000)\end{array}$ & $\begin{array}{c}3.518 \\
(0.318)\end{array}$ & $\begin{array}{l}14.902 \\
(0.002)\end{array}$ & $\begin{array}{l}34.408 \\
(0.000)\end{array}$ & $\begin{array}{c}0.919 \\
(0.821)\end{array}$ & $\begin{array}{l}18.156 \\
(0.000)\end{array}$ \\
\hline Hansen & $\begin{array}{c}6.669 \\
(0.246)\end{array}$ & $\begin{array}{c}0.059 \\
(0.971)\end{array}$ & $\begin{array}{c}0.207 \\
(0.902)\end{array}$ & $\begin{array}{l}11.452 \\
(0.043)\end{array}$ & $\begin{array}{c}0.162 \\
(0.922)\end{array}$ & $\begin{array}{c}0.201 \\
(0.904)\end{array}$ \\
\hline
\end{tabular}

Significance levels: * $10 \%, * * 5 \%, * * * 1 \%$.

Robust standard errors shown in paranthesis under the coefficient estimates.

F-test for joint significance of controls is distributed as:

$\mathrm{F}(6,42)$ for 1987-92, $\mathrm{F}(6,126)$ for 1993-2004 and $\mathrm{F}(7,185)$ for 1987-2004.

Str. break: $\mathrm{H}_{0}=$ no structural break.

We now discuss the results by type of taxable product, beginning with still wine. In the baseline model, we see that $\beta$, the coefficient on $\tau_{-i}$, is insignificantly different from zero but $\gamma$, the coefficient on $D \times \tau_{-i}$, is significantly positive at 0.28 . That is, there is evidence of strategic interaction only after 1993. Specifically, an increase in the weighted average of all other countries' duties on wine by 1 euro increases country $i$ 's excise by 0.28 euro. Turning to the control variables, we see first that total population is significantly positive, a pattern that is repeated across other taxes. This is interesting because it confirms a robust prediction of the theory that larger countries have higher taxes in the origin regime, because they have a larger domestic tax base (Kanbur and Keen, 1993).

In the general structural break model, the key finding about increased strategic interaction is replicated. Before 1993, $\beta_{1}$, the coefficient on $\tau_{-i}$, is insignificantly different from zero but, after 1993 , it is significantly positive at 0.423 . That is, an increase in the weighted average of all other countries' duties on wine by 1 euro increases (C) The Author(s). Journal compilation (c) Royal Economic Society 2009 
Table 3

Estimates for Beer and Ethyl Alcohol Taxes

\begin{tabular}{|c|c|c|c|c|c|c|}
\hline & \multicolumn{3}{|c|}{ Beer } & \multicolumn{3}{|c|}{ Ethyl Alcohol } \\
\hline & & 1987-92 & 1993-2004 & & 1987-92 & 1993-2004 \\
\hline $\begin{array}{l}\tau_{-i} \\
D \times \tau_{-i}\end{array}$ & $\begin{array}{c}0.130 \\
(0.200)\end{array}$ & $\begin{array}{c}0.215 \\
(0.456)\end{array}$ & $\begin{array}{c}0.309 * \\
(0.175)\end{array}$ & $\begin{array}{l}-0.260 \\
(0.496)\end{array}$ & $\begin{array}{c}0.334 \\
(0.320)\end{array}$ & $\begin{array}{l}0.649 * * \\
(0.257)\end{array}$ \\
\hline$D \times \tau_{-i}$ & $\begin{array}{l}0.199 * * \\
(0.084)\end{array}$ & & & $\begin{array}{l}0.261 * * \\
(0.115)\end{array}$ & & \\
\hline Total population & $\begin{array}{l}0.021 * * * \\
(0.006)\end{array}$ & $\begin{array}{c}0.016 \\
(0.012)\end{array}$ & $\begin{array}{l}0.021^{* *} \\
(0.009)\end{array}$ & $\begin{array}{c}7.162 \\
(4.913)\end{array}$ & $\begin{array}{l}20.414 * * \\
(9.344)\end{array}$ & $\begin{array}{l}1.673 \\
(2.619)\end{array}$ \\
\hline$g d p p c$ & $\begin{array}{l}-0.003 * * * \\
(0.001)\end{array}$ & $\begin{array}{c}0.003 \\
(0.004)\end{array}$ & $\begin{array}{c}-0.000 \\
(0.001)\end{array}$ & $\begin{array}{l}2.294^{* *} \\
(1.008)\end{array}$ & $\begin{array}{c}-3.546 \\
(5.345)\end{array}$ & $\begin{array}{c}2.300 * \\
(1.287)\end{array}$ \\
\hline govcons & $\begin{array}{c}0.036 \\
(0.035)\end{array}$ & $\begin{array}{c}0.082 \\
(0.053)\end{array}$ & $\begin{array}{c}0.033 \\
(0.035)\end{array}$ & $\begin{array}{c}15.633 \\
(18.896)\end{array}$ & $\begin{array}{c}48.981 \\
(31.459)\end{array}$ & $\begin{array}{c}0.971 \\
(20.409)\end{array}$ \\
\hline govright & $\begin{array}{c}0.078 \\
(0.111)\end{array}$ & $\begin{array}{c}0.003 \\
(0.063)\end{array}$ & $\begin{array}{c}0.037 \\
(0.108)\end{array}$ & $\begin{array}{c}-21.713 \\
(58.550)\end{array}$ & $\begin{array}{c}5.584 \\
(55.096)\end{array}$ & $\begin{array}{c}-40.644 \\
(83.888)\end{array}$ \\
\hline govleft & $\begin{array}{c}0.002 \\
(0.123)\end{array}$ & $\begin{array}{c}0.045 \\
(0.139)\end{array}$ & $\begin{array}{c}0.016 \\
(0.139)\end{array}$ & $\begin{array}{r}-57.364 \\
(85.777)\end{array}$ & $\begin{array}{c}139.213 \\
(105.619)\end{array}$ & $\begin{array}{r}-180.054 \\
(113.589)\end{array}$ \\
\hline$N$ & 204 & 60 & 144 & 204 & 60 & 144 \\
\hline F-test & $\begin{array}{c}6.643 \\
(0.000)\end{array}$ & $\begin{array}{c}2.468 \\
(0.039)\end{array}$ & $\begin{array}{c}1.966 \\
(0.075)\end{array}$ & $\begin{array}{c}16.950 \\
(0.000)\end{array}$ & $\begin{array}{c}3.854 \\
(0.004)\end{array}$ & $\begin{array}{c}10.286 \\
(0.000)\end{array}$ \\
\hline \multicolumn{2}{|l|}{ Str. break } & \multicolumn{2}{|c|}{ Reject $\mathrm{H}_{0}$} & & \multicolumn{2}{|c|}{ Reject $\mathrm{H}_{0}$} \\
\hline Pagan-H & $\begin{array}{l}74.158 \\
(0.000)\end{array}$ & $\begin{array}{l}17.019 \\
(0.652)\end{array}$ & $\begin{array}{l}66.545 \\
(0.000)\end{array}$ & $\begin{array}{r}105.660 \\
(0.000)\end{array}$ & $\begin{array}{l}36.206 \\
(0.010)\end{array}$ & $\begin{array}{l}79.249 \\
(0.000)\end{array}$ \\
\hline $\mathrm{F}_{I V_{1}}$ & $\begin{array}{c}9.174 \\
(0.000)\end{array}$ & $\begin{array}{l}1.420 \\
(0.245)\end{array}$ & $\begin{array}{c}4.093 \\
(0.004)\end{array}$ & $\begin{array}{c}22.288 \\
(0.000)\end{array}$ & $\begin{array}{l}12.938 \\
(0.000)\end{array}$ & $\begin{array}{l}18.037 \\
(0.000)\end{array}$ \\
\hline $\mathrm{F}_{I V_{2}}$ & $\begin{array}{c}7.105 \\
(0.000)\end{array}$ & & & $\begin{array}{l}99.926 \\
(0.000)\end{array}$ & & \\
\hline Anderson & $\begin{array}{l}63.282 \\
(0.000)\end{array}$ & $\begin{array}{c}4.635 \\
(0.327)\end{array}$ & $\begin{array}{l}18.536 \\
(0.001)\end{array}$ & $\begin{array}{l}39.793 \\
(0.000)\end{array}$ & $\begin{array}{l}12.314 \\
(0.006)\end{array}$ & $\begin{array}{l}26.534 \\
(0.000)\end{array}$ \\
\hline Hansen & $\begin{array}{l}10.320 \\
(0.112)\end{array}$ & $\begin{array}{c}3.673 \\
(0.299)\end{array}$ & $\begin{array}{c}7.129 \\
(0.068)\end{array}$ & $\begin{array}{c}9.717 \\
(0.205)\end{array}$ & $\begin{array}{c}4.251 \\
(0.119)\end{array}$ & $\begin{array}{c}1.342 \\
(0.511)\end{array}$ \\
\hline
\end{tabular}

Significance levels: * $10 \%, * * 5 \%, * * * 1 \%$.

Robust standard errors shown in parenthesis under the coefficient estimates.

F-test for joint significance of controls is distributed as:

$\mathrm{F}(6,42)$ for $1987-92, \mathrm{~F}(6,126)$ for $1993-2004$ and $\mathrm{F}(7,185)$ for 1987-2004.

Str. break: $\mathrm{H}_{0}=$ no structural break.

country $i$ 's excise by approximately 0.42 euro. There is some instability in the coefficients on the control variables, however; these are markedly different during the period 1987-92 from both the period 1993-2004 and the single estimate for the tax-specific structural break model; the latter two are much closer to each other. This may indicate overfitting for the regressions over the period 1987-92, where six coefficients are estimated from just 60 observations. This pattern of markedly different coefficients for the period 1987-92 appears right across the six taxes.

Turning now to the tax on sparkling wine, the same general pattern emerges. In the baseline model, we see that $\beta$, the coefficient on $\tau_{-i}$, is insignificantly different from zero but $\gamma$, the coefficient on $D \times \tau_{-i}$, is significantly positive at 0.206 . That is, there is evidence of strategic interaction only after 1993. Specifically, an increase in the weighted average of all other countries' duties on wine by 1 euro increases country $i$ 's excise by approximately 0.21 euro. In the general structural break model, the key finding about

(C) The Author(s). Journal compilation (C) Royal Economic Society 2009 
Table 4

Estimates for Cigarettes Taxes

\begin{tabular}{|c|c|c|c|c|c|c|}
\hline & \multicolumn{3}{|c|}{ Cigarettes specific } & \multicolumn{3}{|c|}{ Cigarettes total } \\
\hline & & 1987-92 & 1993-2004 & & 1987-92 & 1993-2004 \\
\hline$\tau_{-i}$ & $\begin{array}{l}1.070 * * * * \\
(0.251)\end{array}$ & $\begin{array}{l}0.497 * * * * \\
(0.182)\end{array}$ & $\begin{array}{l}1.320 * * * \\
(0.277)\end{array}$ & $\begin{array}{l}0.761 * * * \\
(0.128)\end{array}$ & $\begin{array}{l}1.070 * * * \\
(0.091)\end{array}$ & $\begin{array}{l}1.007 * * * \\
(0.058)\end{array}$ \\
\hline$D \times \tau_{-i}$ & $\begin{array}{c}-0.045 \\
(0.156)\end{array}$ & & & $\begin{array}{l}0.074^{* *} \\
(0.031)\end{array}$ & & \\
\hline Total population & $\begin{array}{c}0.187 \\
(0.169)\end{array}$ & $\begin{array}{l}0.560 * * * \\
(0.126)\end{array}$ & $\begin{array}{c}-0.280 \\
(0.320)\end{array}$ & $\begin{array}{c}-0.019 \\
(0.039)\end{array}$ & $\begin{array}{c}-0.072 \\
(0.180)\end{array}$ & $\begin{array}{c}-0.028 \\
(0.054)\end{array}$ \\
\hline$g d p p c$ & $\begin{array}{c}-0.045^{* *} \\
(0.020)\end{array}$ & $\begin{array}{c}-0.035 \\
(0.033)\end{array}$ & $\begin{array}{c}-0.079 * * \\
(0.039)\end{array}$ & $\begin{array}{c}-0.005 \\
(0.004)\end{array}$ & $\begin{array}{c}-0.044^{*} \\
(0.025)\end{array}$ & $\begin{array}{c}-0.004 \\
(0.007)\end{array}$ \\
\hline govcons & $\begin{array}{c}1.932^{*} \\
(1.020)\end{array}$ & $\begin{array}{c}0.726^{*} \\
(0.428)\end{array}$ & $\begin{array}{c}3.624^{* *} \\
(1.593)\end{array}$ & $\begin{array}{c}-0.256 \\
(0.287)\end{array}$ & $\begin{array}{c}-0.242 \\
(0.675)\end{array}$ & $\begin{array}{c}-0.815^{*} \\
(0.481)\end{array}$ \\
\hline govright & $\begin{array}{c}1.973 \\
(2.722)\end{array}$ & $\begin{array}{c}-0.146 \\
(0.998)\end{array}$ & $\begin{array}{c}5.389 \\
(4.079)\end{array}$ & $\begin{array}{c}0.674 \\
(0.923)\end{array}$ & $\begin{array}{l}1.462 \\
(2.209)\end{array}$ & $\begin{array}{c}0.066 \\
(1.097)\end{array}$ \\
\hline govleft & $\begin{array}{c}0.613 \\
(3.319)\end{array}$ & $\begin{array}{c}1.293 \\
(1.298)\end{array}$ & $\begin{array}{c}6.941 \\
(4.569)\end{array}$ & $\begin{array}{c}-0.755 \\
(1.211)\end{array}$ & $\begin{array}{c}1.075 \\
(2.860)\end{array}$ & $\begin{array}{c}-2.003 \\
(1.256)\end{array}$ \\
\hline$N$ & 204 & 60 & 144 & 204 & 60 & 144 \\
\hline F-test & $\begin{array}{c}14.113 \\
(0.000)\end{array}$ & $\begin{array}{c}7.974 \\
(0.000)\end{array}$ & $\begin{array}{c}8.797 \\
(0.000)\end{array}$ & $\begin{array}{c}67.248 \\
(0.000)\end{array}$ & $\begin{array}{l}30.853 \\
(0.000)\end{array}$ & $\begin{array}{c}50.435 \\
(0.000)\end{array}$ \\
\hline Str. break & \multicolumn{4}{|c|}{ Reject $\mathrm{H}_{0}$} & \multicolumn{2}{|c|}{ Reject $\mathrm{H}_{0}$} \\
\hline Pagan-H & $\begin{array}{l}91.089 \\
(0.000)\end{array}$ & $\begin{array}{l}21.111 \\
(0.391)\end{array}$ & $\begin{array}{c}55.899 \\
(0.000)\end{array}$ & $\begin{array}{l}71.354 \\
(0.000)\end{array}$ & $\begin{array}{c}18.804 \\
(0.535)\end{array}$ & $\begin{array}{l}48.517 \\
(0.000)\end{array}$ \\
\hline $\mathrm{F}_{I V_{1}}$ & $\begin{array}{c}5.911 \\
(0.000)\end{array}$ & $\begin{array}{l}11.525 \\
(0.000)\end{array}$ & $\begin{array}{c}2.817 \\
(0.028)\end{array}$ & $\begin{array}{c}89.266 \\
(0.000)\end{array}$ & $\begin{array}{l}33.204 \\
(0.000)\end{array}$ & $\begin{array}{l}17.360 \\
(0.000)\end{array}$ \\
\hline $\mathrm{F}_{I V_{2}}$ & $\begin{array}{c}8.220 \\
(0.000)\end{array}$ & & & $\begin{array}{r}292.137 \\
(0.000)\end{array}$ & & \\
\hline Anderson & $\begin{array}{l}40.331 \\
(0.000)\end{array}$ & $\begin{array}{c}13.785 \\
(0.008)\end{array}$ & $\begin{array}{c}13.338 \\
(0.010)\end{array}$ & $\begin{array}{c}34.398 \\
(0.000)\end{array}$ & $\begin{array}{l}19.995 \\
(0.001)\end{array}$ & $\begin{array}{l}38.892 \\
(0.000)\end{array}$ \\
\hline Hansen & $\begin{array}{l}13.684 \\
(0.057)\end{array}$ & $\begin{array}{c}0.378 \\
(0.945)\end{array}$ & $\begin{array}{c}4.511 \\
(0.211)\end{array}$ & $\begin{array}{c}6.384 \\
(0.172)\end{array}$ & $\begin{array}{l}5.928 \\
(0.115)\end{array}$ & $\begin{array}{c}2.637 \\
(0.451)\end{array}$ \\
\hline
\end{tabular}

Significance levels: $* 10 \%, * * 5 \%, * * * 1 \%$.

Robust standard errors shown in parenthesis under the coefficient estimates.

F-test for joint significance of controls is distributed as:

$\mathrm{F}(6,42)$ for $1987-92, \mathrm{~F}(6,126)$ for $1993-2004$ and $\mathrm{F}(7,185)$ for 1987-2004.

Str. break: $\mathrm{H}_{0}=$ no structural break.

increased strategic interaction is replicated. Before 1993, $\beta_{1}$, the coefficient on $\tau_{-i}$, is insignificantly different from zero, but after $1993, \beta_{2}$ is significantly positive ${ }^{22}$ at 1.215.

In Table 3, the same story is also apparent for the specific taxes on beer and ethyl alcohol. For beer, in the baseline model, we see that $\beta$, the coefficient on $\tau_{-i}$, is insignificantly different from zero but $\gamma$, the coefficient on $D \times \tau_{-i}$, is significantly positive at 0.199 . In the general structural break model, the key finding about increased strategic interaction is again replicated. Before 1993, $\beta_{1}$, the coefficient on $\tau_{-i}$, is insignificantly different from zero but, after 1993, $\beta_{2}$ is significantly positive at 0.309 . For ethyl alcohol, in the baseline model, we see that $\beta$, the coefficient on $\tau_{-i}$, is insignificantly different from zero but $\gamma$, the coefficient on $D \times \tau_{-i}$, is significantly positive at 0.261 . In the general structural break model, before $1993, \beta_{1}$ is insignificantly different from zero but, after $1993, \beta_{2}$ is significantly positive at 0.649 .

\footnotetext{
${ }^{22}$ It is worth noting that the usual models of excise tax competition under the origin principle generate tax reaction functions with a slope of less than one, so this coefficient is not fully consistent with the theory.

(C) The Author(s). Journal compilation (c) Royal Economic Society 2009
} 
However, in Table 4, the story comes though less clearly for taxes on cigarettes. First, unlike for the other four products, there is evidence of strategic interaction prior to 1993. Specifically, for both model specifications and for both the specific component of the tax and the total tax, there is evidence of significant strategic interaction prior to 1993 . Second, for the baseline model with a tax-specific structural break, there is evidence of increased strategic interaction (i.e. a positive $\gamma$ ) only for the total tax, whereas in the other specification, the reverse is true. One possible explanation for this discrepancy is that, as discussed in the introduction, the problem of illegal smuggling is much more serious for cigarettes and other tobacco products than it is for the other products.

\section{Robustness Checks}

\subsection{No Country Characteristics}

In the general structural break model, there is a potential problem of overfitting: six parameters are estimated on just 60 observations. This manifests itself in two ways. First, the coefficients on the control variables vary noticeably across the two sub-periods. Moreover, the controls are jointly insignificant in the case of still and sparkling wine in the first sub-period. As a robustness check, therefore, we estimate the general structural break model without controls i.e. just with country fixed effects. The results are reported in Table 5 .

This Table shows that our main results on strategic interaction are generally robust to the omission of the controls. That is, same pattern of coefficients on $\tau_{-i}$ emerges, with one exception. This is that there is now evidence of strategic interaction in the beer excise prior to 1993, with the reaction function slope actually being larger prior to 1993 than afterwards. However, in the case of beer, the controls are jointly significant prior to 1993, and so omission of the controls may lead to bias, and thus perhaps not too much weight should be placed on this.

\subsection{Alternative Weighting Schemes}

So far, we have weighted other countries' taxes using contiguity weights. Given the nature of commodity tax competition, these seem to be clearly the appropriate weights. However, we conduct several robustness checks to see if they indeed do work better than other weighting schemes. In Table 6 , only the reaction function slope coefficients are reported, although controls and fixed effects are included in all regressions.

What do we expect to find with other weights? Suppose that the data are really being generated by a process of tax competition between geographical neighbours after 1993 only. Then, we expect other weights to show weaker evidence of strategic interaction and this evidence should be poorer, the more different the other weights are from contiguity weights. This is broadly what we do find.

First, we look at modified contiguity weights, or triangulation weights, generated by Delauney triangulation. ${ }^{23}$ This works as follows. Each country is identified by a point in

\footnotetext{
${ }^{23}$ Kelley Pace has written the code (FDELW2.m) to convert Delauney algorithm results into a contiguity matrix. The code is included in his Spatial Statistics toolbox 2.0 for Matlab, which can be downloaded from www.spatial-statistics.com.
}

(C) The Author(s). Journal compilation (C) Royal Economic Society 2009 
Table 5

All Taxes - No Country Controls

\begin{tabular}{|c|c|c|c|c|}
\hline & \multicolumn{2}{|c|}{ Still Wine } & \multicolumn{2}{|c|}{ Sparkling Wine } \\
\hline & 1987-92 & 1993-2004 & 1987-92 & 1993-2004 \\
\hline$\tau_{-i}$ & $\begin{array}{c}-0.661 \\
(1.235)\end{array}$ & $\begin{array}{l}0.684^{* * * *} \\
(0.216)\end{array}$ & $\begin{array}{c}-0.142 \\
(0.936)\end{array}$ & $\begin{array}{l}1.009 \text { **** } \\
(0.204)\end{array}$ \\
\hline Anderson & $\begin{array}{c}8.970 \\
(0.030)\end{array}$ & $\begin{array}{l}18.136 \\
(0.000)\end{array}$ & $\begin{array}{c}8.115 \\
(0.044)\end{array}$ & $\begin{array}{l}35.276 \\
(0.000)\end{array}$ \\
\hline Hansen & $\begin{array}{c}1.661 \\
(0.436)\end{array}$ & $\begin{array}{c}0.022 \\
(0.989)\end{array}$ & $\begin{array}{c}3.391 \\
(0.184)\end{array}$ & $\begin{array}{c}0.041 \\
(0.980)\end{array}$ \\
\hline \multirow[t]{2}{*}{ Str. break } & \multicolumn{2}{|c|}{ Reject $\mathrm{H}_{0}$} & \multicolumn{2}{|c|}{ Reject $\mathrm{H}_{0}$} \\
\hline & \multicolumn{2}{|c|}{ Beer } & \multicolumn{2}{|c|}{ Ethyl Alcohol } \\
\hline$\tau_{-i}$ & $\begin{array}{l}0.725^{* * * *} \\
(0.237)\end{array}$ & $\begin{array}{l}0.715^{* * *} \\
(0.243)\end{array}$ & $\begin{array}{c}0.241 \\
(0.563)\end{array}$ & $\begin{array}{l}1.194^{* * * *} \\
(0.253)\end{array}$ \\
\hline Anderson & $\begin{array}{c}19.234 \\
(0.001)\end{array}$ & $\begin{array}{c}32.952 \\
(0.000)\end{array}$ & $\begin{array}{l}20.993 \\
(0.000)\end{array}$ & $\begin{array}{l}38.250 \\
(0.000)\end{array}$ \\
\hline Hansen & $\begin{array}{c}3.490 \\
(0.322)\end{array}$ & $\begin{array}{c}5.936 \\
(0.115)\end{array}$ & $\begin{array}{c}4.389 \\
(0.111)\end{array}$ & $\begin{array}{c}2.349 \\
(0.309)\end{array}$ \\
\hline \multirow[t]{2}{*}{ Str. break } & \multicolumn{2}{|c|}{ Reject $\mathrm{H}_{0}$} & \multicolumn{2}{|c|}{ Reject $\mathrm{H}_{0}$} \\
\hline & \multicolumn{2}{|c|}{ Cigarettes specific } & \multicolumn{2}{|c|}{ Cigarettes total } \\
\hline$\tau_{-i}$ & $\begin{array}{l}0.556^{* * *} \\
(0.118)\end{array}$ & $\begin{array}{l}1.056^{* * *} \\
(0.160)\end{array}$ & $\begin{array}{l}1.071 * * * \\
(0.082)\end{array}$ & $\begin{array}{l}0.986^{* * * *} \\
(0.062)\end{array}$ \\
\hline Anderson & $\begin{array}{l}14.329 \\
(0.006)\end{array}$ & $\begin{array}{c}36.945 \\
(0.000)\end{array}$ & $\begin{array}{c}19.514 \\
(0.001)\end{array}$ & $\begin{array}{l}38.301 \\
(0.000)\end{array}$ \\
\hline Hansen & $\begin{array}{c}2.154 \\
(0.541)\end{array}$ & $\begin{array}{c}1.991 \\
(0.574)\end{array}$ & $\begin{array}{c}4.868 \\
(0.182)\end{array}$ & $\begin{array}{c}2.147 \\
(0.542)\end{array}$ \\
\hline Str. break & \multicolumn{2}{|c|}{ Reject $\mathrm{H}_{0}$} & \multicolumn{2}{|c|}{ Reject $\mathrm{H}_{0}$} \\
\hline
\end{tabular}

Significance levels: * 10\%, ** 5\%, *** $1 \%$.

Robust standard errors shown in parenthesis under the coefficient estimates.

F-test for joint significance of controls is distributed as:

$\mathrm{F}(1,47)$ for 1987-92, $\mathrm{F}(1,131)$ for 1993-2004 and $\mathrm{F}(2,190)$ for 1987-2004.

Str. break: $\mathrm{H}_{0}=$ no structural break.

the plane (i.e. $\mathcal{R}^{2}$ ) given by the longitude and latitude coordinates of the capital. These points are then joined in such a way that all of the space is subdivided in triangles. Now if a country $i$ shares an edge with country $j$, then the two countries are contiguous and in the weight matrix $\omega_{i j}=1$, otherwise $\omega_{i j}=0$. There are two different versions of this weight matrix, the first being symmetric and the second being row-normalised. These weights have the advantage that they deal systematically, rather than in an ad hoc way, with countries that are islands or separated by sea from other countries, of which there are quite a few in our sample.

As the triangulation weights are positively, although not perfectly, correlated with our baseline contiguity weights, we would expect the regressions with triangulation weights to still show evidence of strategic interaction after 1993 but less clearly than with contiguity weights. ${ }^{24}$ This is more or less what we see in Table 6 . Looking first at

${ }^{24}$ For example, in our baseline weighting scheme, Greece only has Italy as a neighbour but, in the triangulation scheme, it also has Spain, Portugal, Germany and Denmark.

(C) The Author(s). Journal compilation (C) Royal Economic Society 2009 
Table 6

Estimates With Other Weighting Schemes

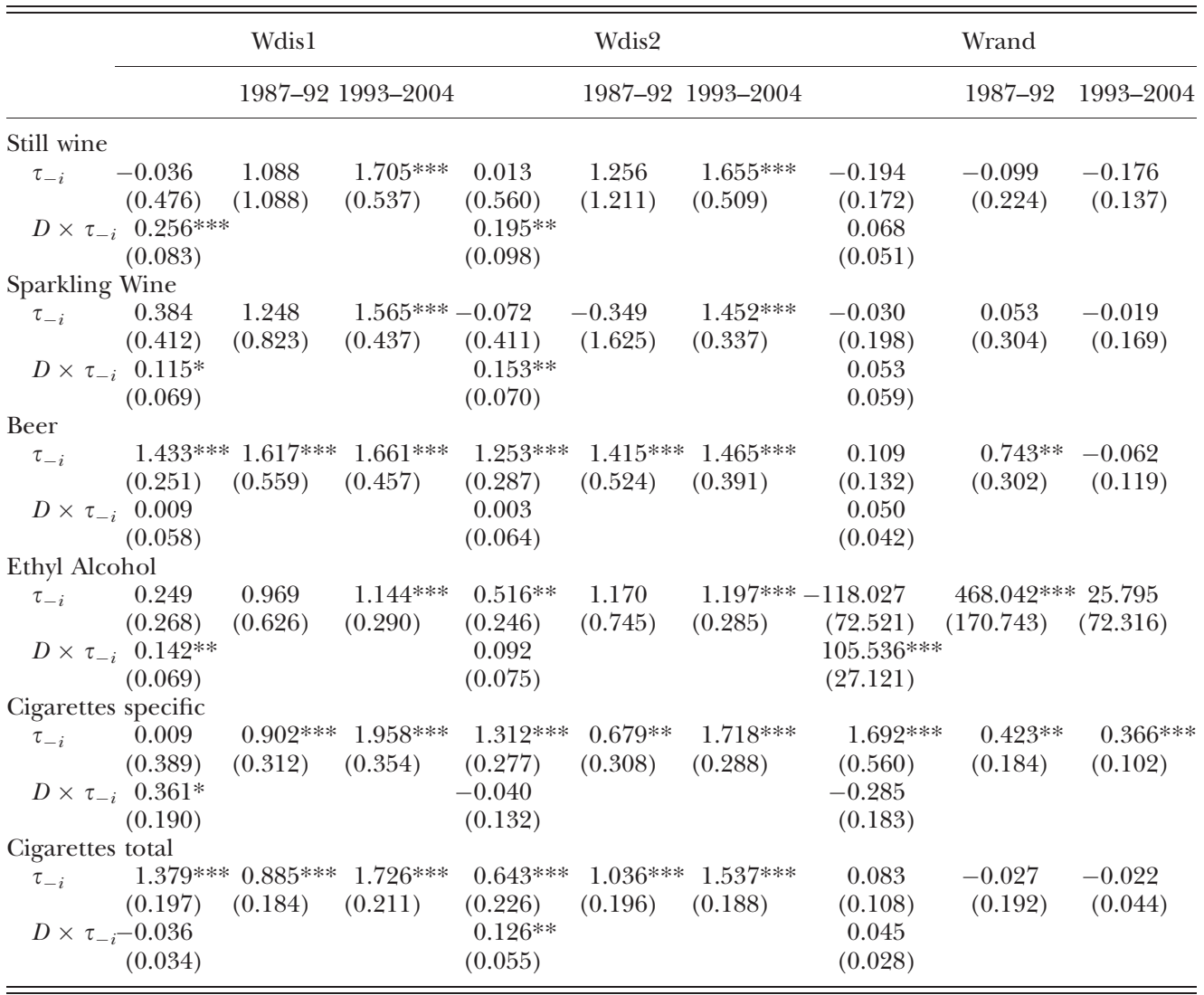

Significance levels: * 10\%, ** 5\%, *** $1 \%$.

Robust standard errors shown in parenthesis under the coefficient estimates.

F-test for joint significance of controls is distributed as:

$\mathrm{F}(6,42)$ for $1987-92, \mathrm{~F}(6,126)$ for $1993-2004$ and $\mathrm{F}(7,185)$ for 1987-2004.

Str. break: $\mathrm{H}_{0}=$ no structural break.

the tax-specific structural break model, i.e. comparing columns 1 and 4 of Table 6 to the relevant columns of Tables $2-4$ we see that this is what happens. ${ }^{25}$

Finally, we compare contiguity weights to 'placebo' weights which are chosen in some random way without regard to any economic considerations. Following Case et al. (1992), we construct a weighting matrix based on a 'nonsense' procedure; $\omega_{i j}>0$ only if the name of country $j$ comes after country $i$ in the alphabet. ${ }^{26}$ If we continue to find evidence of strategic interaction with these placebo weights after 1993, that might

\footnotetext{
${ }^{25}$ Specifically, for the first triangulation weights, the main changes are as follows. Strategic interaction in sparkling wine excises is now only significant at $10 \%$ after 1993 . There is now evidence of strategic interaction in beer excises before 1993 which does not intensify after 1993. There is now no evidence of strategic interaction in specific cigarette excises before 1993 but some evidence (a positive coefficient significant at 10\%) of interaction after 1993. Competition in the total tax on cigarettes does not seem to intensify after 1993. A similar comparison can be made for the second triangulation weight.

26 The weights are also row-normalised in this case.
}

(C) The Author(s). Journal compilation (C) Royal Economic Society 2009 
indicate some general positive correlation between all excise taxes generated by omitted common shocks, which would cast doubt on our claim that we have found evidence of tax competition.

Happily, we see from Table 6 that placebo weights do not show any evidence of positive strategic interaction after 1993, with the exception of specific excises on cigarettes. Looking across commodities and across the two sub-samples, there does not seem to be any pattern in the reaction function slope coefficients at all; most of them are insignificant.

\subsection{Minimum Tax Rates}

So far in the analysis, we have ignored any possible effects of minimum tax rates. Evers et al. (2004), based on the theoretical literature, argue that such rates, if they affect the Nash equilibrium at all, will generally cause rates to rise. For example, in Nielsen's (2001) model, it is easily verified in the two-country case that if the minimum tax is binding on the lower-tax country, it will raise the tax not only in that country but also in the other, high-tax country, as the latter country is moved along its upward-sloping tax reaction function. So, we should expect, other things equal, the minimum tax to increase the intercepts of the reaction functions.

It is less clear how the minimum tax will affect the amount of strategic interaction. Here, we simply follow Evers et al. (2004) by interacting the minimum tax with the weighted average of other countries' taxes. So, given that minimum taxes did not come in force until 1993, we estimate, over the period 1993-2004, an augmented version of (2) i.e.

$$
\tau_{i t}=f_{i}+\beta \tau_{-i, t}+\boldsymbol{\delta}^{\prime} \mathbf{z}_{i t}+\theta m_{t}+\gamma\left(m_{t} \times \tau_{-i, t}\right)+\epsilon_{i t}
$$

where $m_{t}$ is the minimum tax at time $t$ and $\tau_{-i, t}=\sum_{j \neq i} \omega_{i j} \tau_{j t}$. We expect $\theta>0$ and possibly $\gamma \neq 0$. But there are some complications.

First, for wine (still and sparkling) the minimum tax rate is zero, so (5) cannot be estimated for these products. Second, for cigarettes, the minimum tax rate (measured as a percentage of the retail price) has been unchanged since 1993 , at $57 \%$. So, as the minimum tax rate $m_{t}$ is not time-varying in this case, $\theta, \gamma$ cannot be identified from regression (5) just over the period 1993-2004.

For beer the minimum tax rate has been unchanged since 1993, and it is equal to 0.7448 euro per hl/degree Plato or 1.87 euro per hl/degree of alcohol of finished product. So, in real terms, $m_{t}$ is declining and this allows us to estimate (5) in this case. The first column of Table 7 reports the estimation of (5) for beer, using a contiguity weight matrix, and instrumenting both $\tau_{-i, t}$ and $m_{t} \times \tau_{-i, t}$ by weighted averages of the control variables in countries $j \neq i$. The only tax-related variable that is significant is $m_{t} \times \tau_{-i, t}$ with a positive coefficient.

For ethyl alcohol, the picture is similar to beer; the minimum tax rate has been unchanged since 1993 at 500 euro per hl of pure alcohol, is thus declining in real terms, again allowing us to estimate (5). In this case, no tax variables are significant. Given that there are only 204 observations available, perhaps it is asking too much of the data to estimate $\beta, \theta$ and $\gamma$ precisely. 
Table 7

The Effects of the Minimum Tax

\begin{tabular}{lcc}
\hline \hline & Beer & Ethyl Alcohol \\
\hline$\tau_{-i}$ & -0.264 & -0.501 \\
$m \times \tau_{-i}$ & $(0.293)$ & $(0.475)$ \\
& $0.958^{* *}$ & 0.4218 \\
$m$ & $(0.386)$ & $(0.309)$ \\
& -1.029 & 0.119 \\
Total population & $(0.641)$ & $(0.581)$ \\
& $0.021^{* * *}$ & $7.444^{*}$ \\
gdppc & $(0.006)$ & $(4.392)$ \\
& $-0.002 * * *$ & $2.352^{* * *}$ \\
govcons & $(0.001)$ & $(1.037)$ \\
& $0.147 * *$ & 39.091 \\
govright & $(0.073)$ & $(48.322)$ \\
& 0.108 & -3.205 \\
govleft & $(0.142)$ & $(85.722)$ \\
& 0.090 & -50.616 \\
$N$ & $(0.156)$ & $(92.148)$ \\
F-test & 204 & 204 \\
& 7.88 & 20.16 \\
& $(0.000)$ & $(0.000)$ \\
\hline \hline
\end{tabular}

Significance levels: * $10 \%, * * 5 \%, * * * 1 \%$.

Robust standard errors shown in parenthesis under the coefficient estimates.

F-test for joint significance of controls is distributed as: $\mathrm{F}(8,184)$.

\section{Conclusions}

In this work we analysed the effects of the tax competition after the introduction of the Single Market in EU in 1993. Using a panel data set of 12 EU countries over a period of 17 years from 1987 to 2004 and a spatial econometrics approach, we tested for the presence of strategic interaction among neighbouring countries in the setting of five excise taxes. Our work differs most other empirical studies in the same area, as we use actual tax rates as dependent variables and not some derived tax ratio.

Our main finding is a structural break after 1993, indicating that the introduction of the Single Market has modified tax setting among the EU countries. Specifically, for taxes on still and sparkling wine, beer and ethyl alcohol, we can reject the null hypothesis that the slope of the tax reaction function was the same before and after 1993. For these taxes, the reaction function slope is always significantly positive post1993, and never before 1993. This is consistent with the hypothesis that the Single Market created competition between countries in these taxes where there was none before, by making tax bases internationally mobile.

In the case of cigarettes, the findings are somewhat different; the reaction function slope is significantly positive before 1993 but, if the total tax is used, this slope does appear to increase after 1993. This can be explained by the fact that significant smuggling in cigarettes creates incentives for tax competition even if legal transactions are subject to destination-based taxes.

\section{University of Warwick}

Lancaster University

(C) The Author(s). Journal compilation (C) Royal Economic Society 2009 


\section{Appendix Figures}
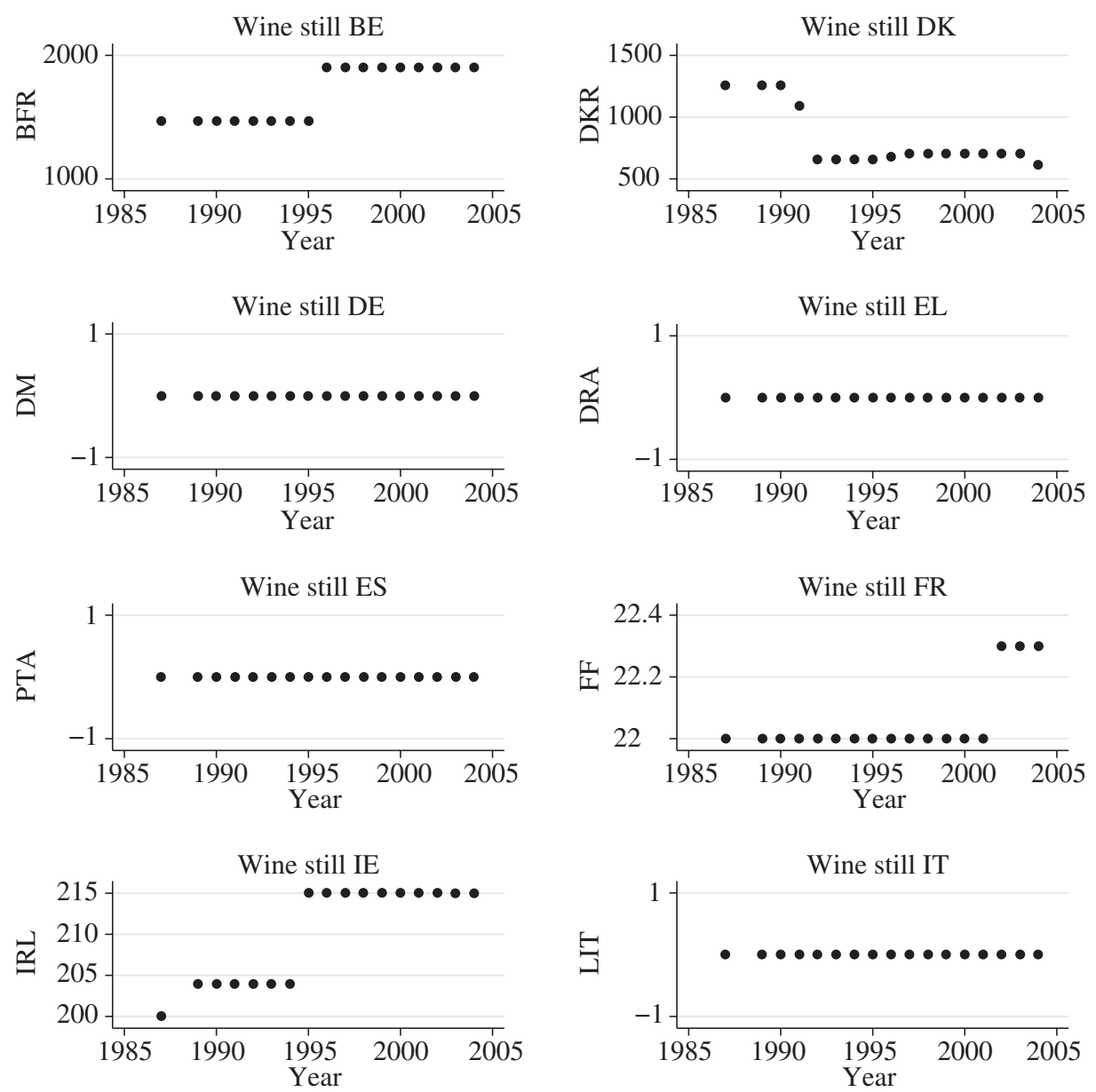

Wine still LU

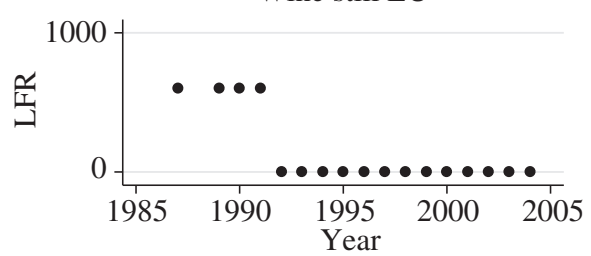

Wine still NL

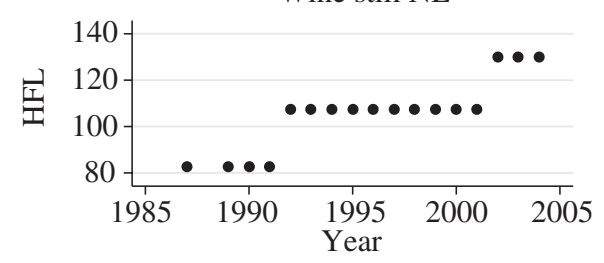

Wine still PT
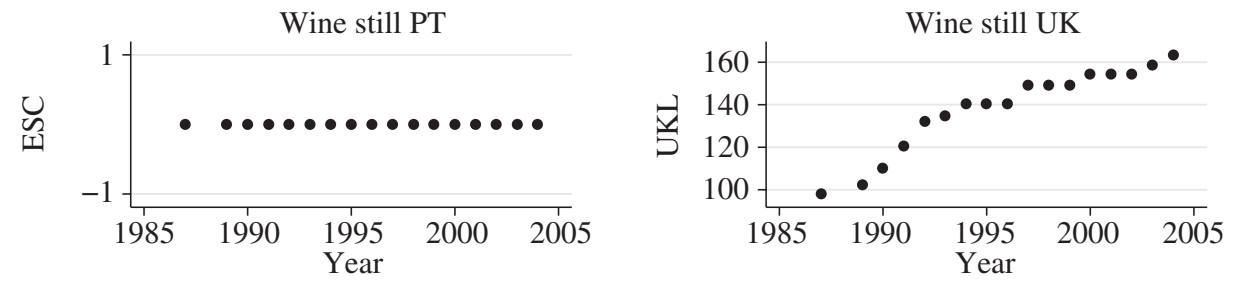

Fig. A.1. Still Wine - Specific Excise in National Currency

(C) The Author(s). Journal compilation (c) Royal Economic Society 2009 

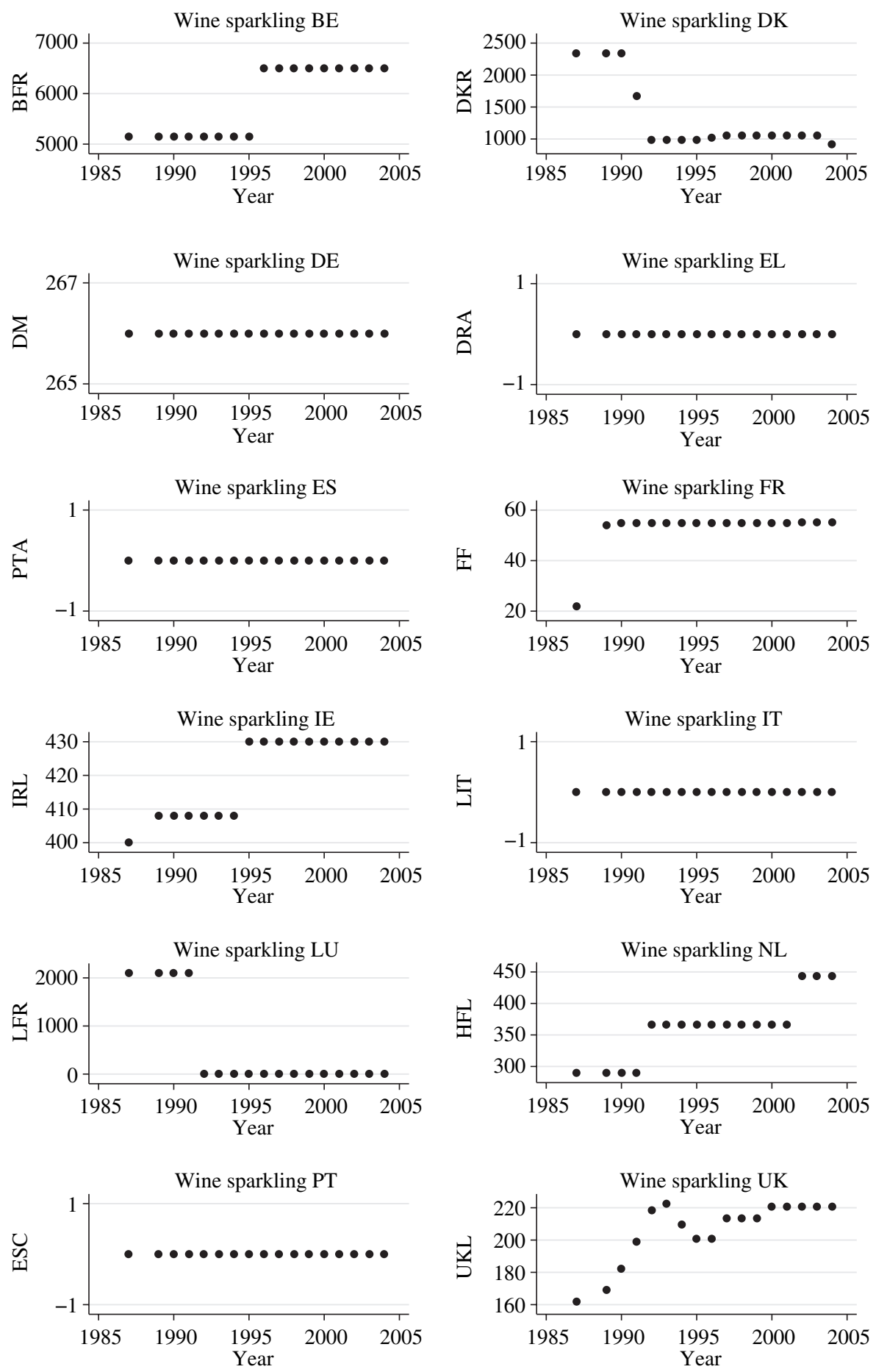

Fig. A.2. Sparkling Wine - Specific Excise in National Currency 

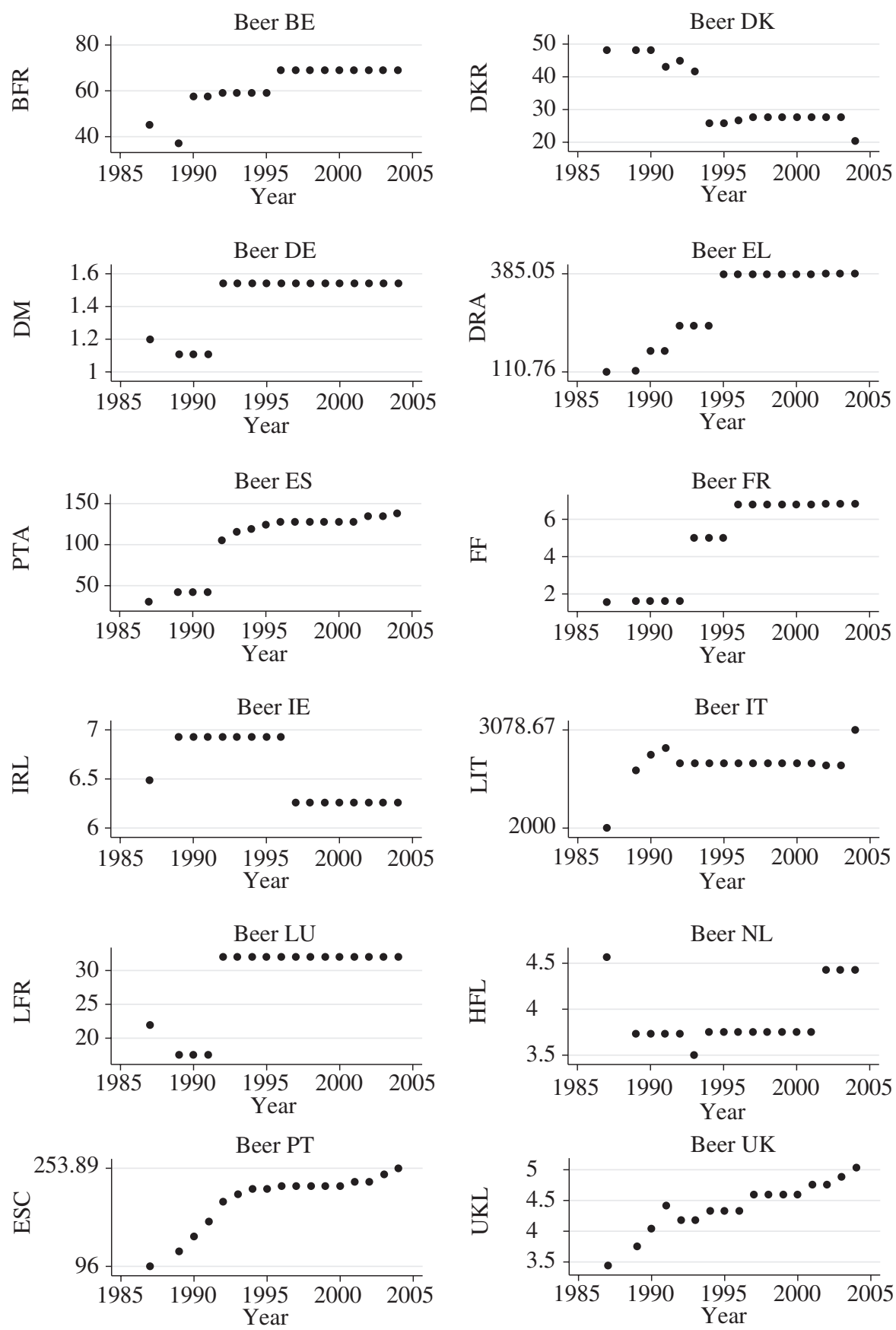

Fig. A.3. Beer - Specific Excise in National Currency 

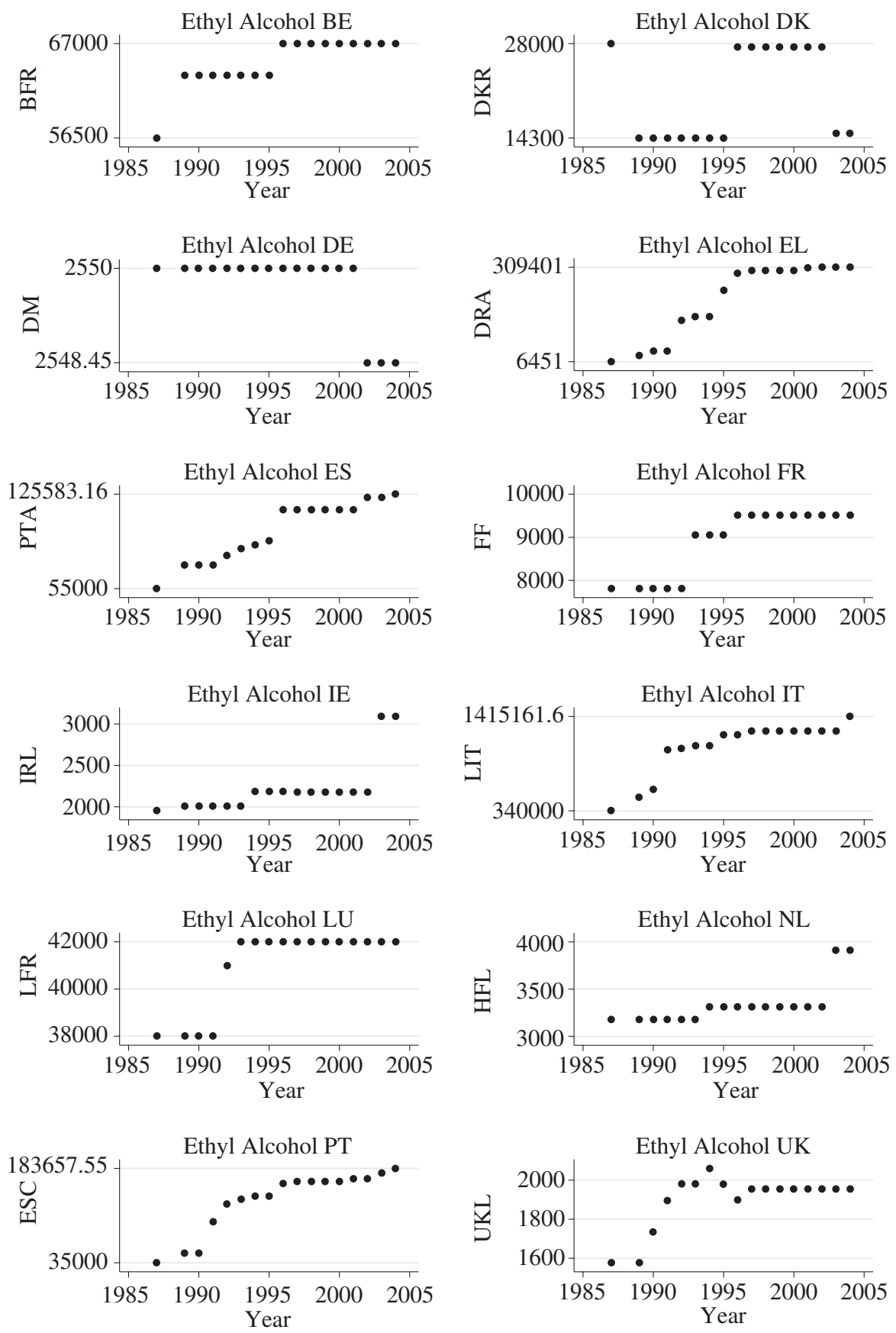

Fig. A.4. Ethyl Alcohol - Specific Excise in National Currency 

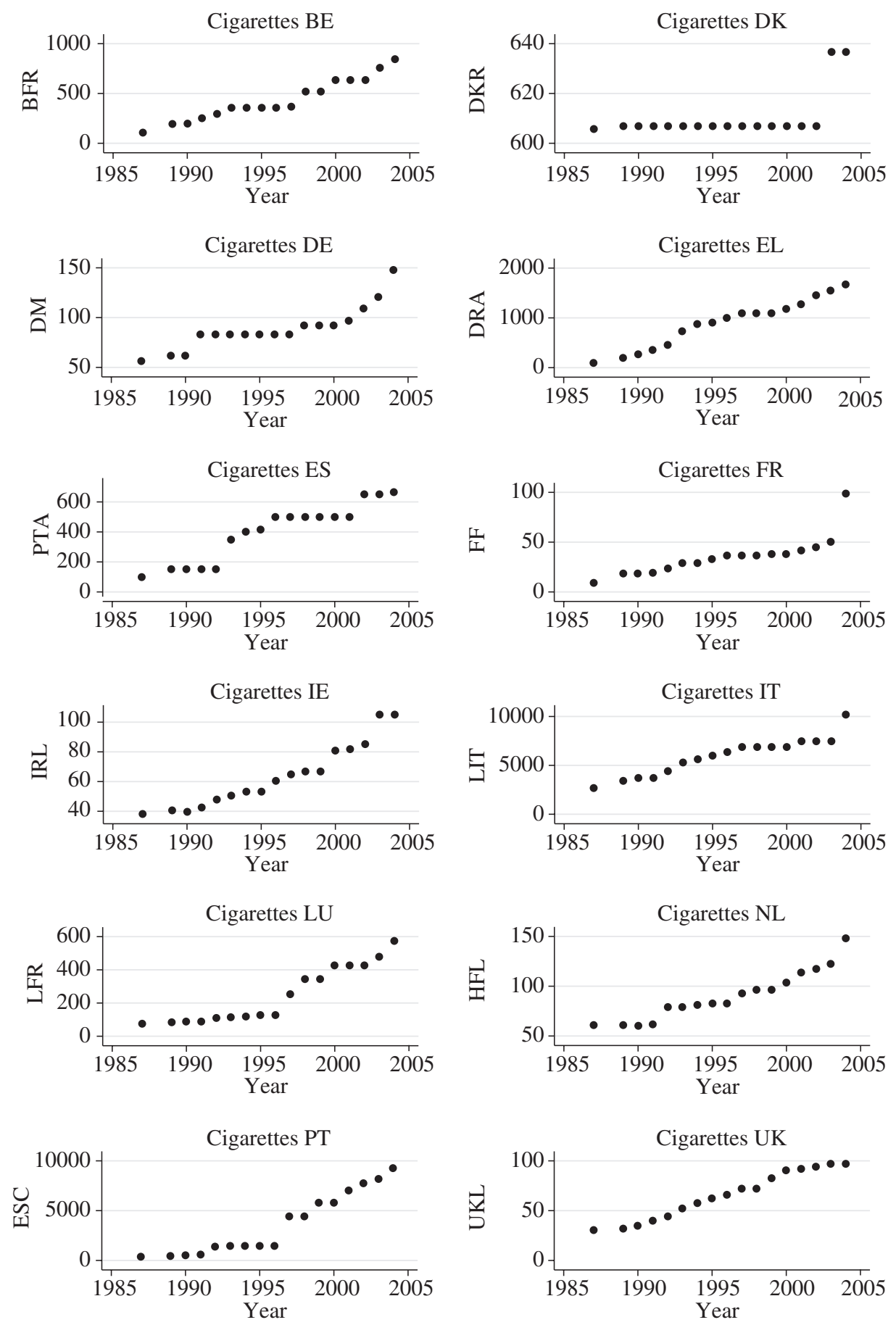

Fig. A.5. Cigarettes - Specific Excise in National Currency 
Cigarettes BE

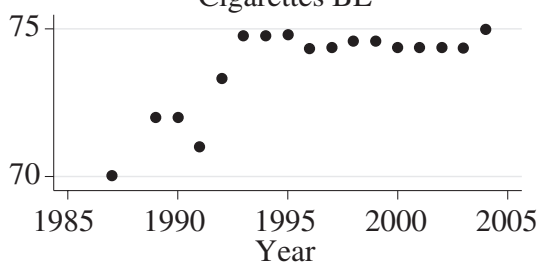

Cigarettes DE

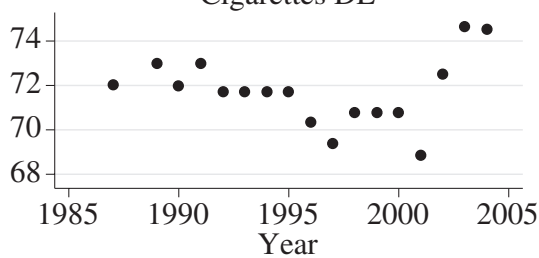

Cigarettes ES

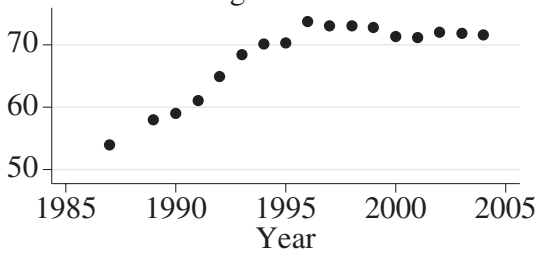

Cigarettes IE

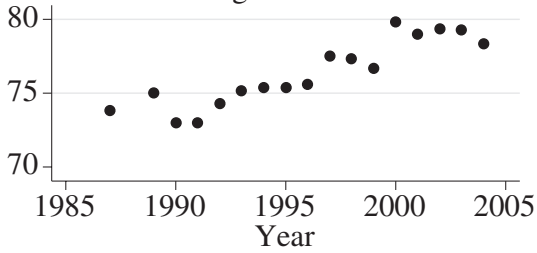

Cigarettes LU

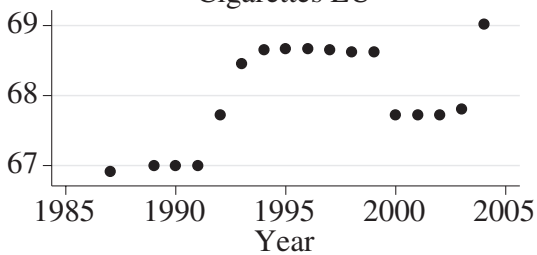

Cigarettes PT

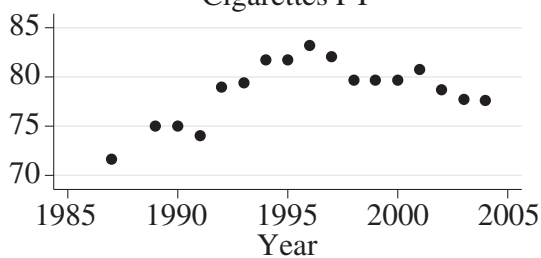

Cigarettes DK

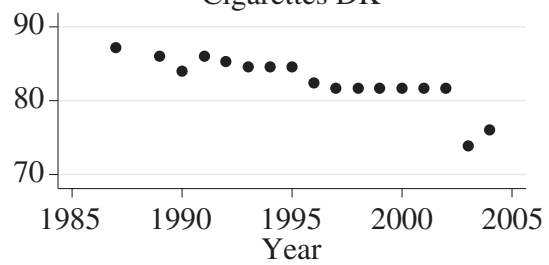

Cigarettes EL

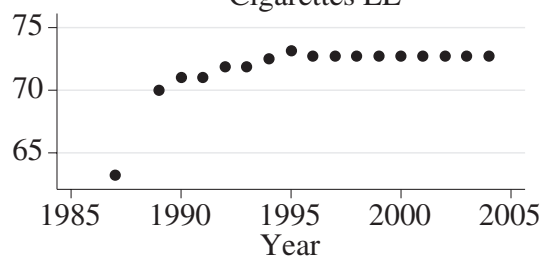

Cigarettes FR

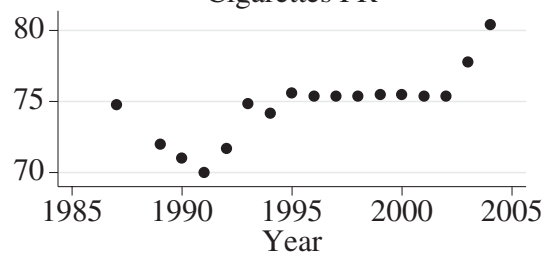

Cigarettes IT

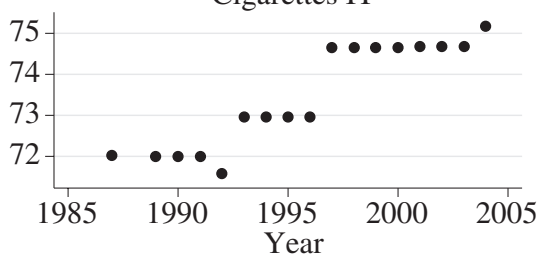

Cigarettes NL

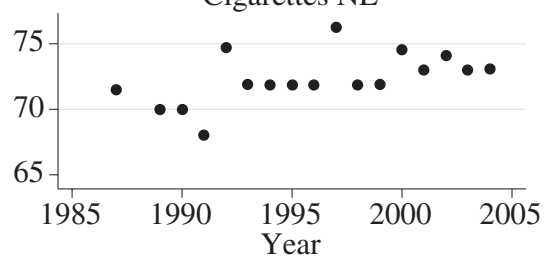

Cigarettes UK

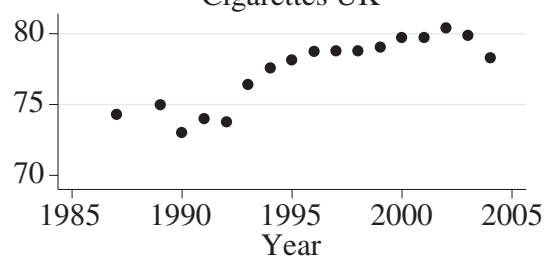

Fig. A.6. Cigarettes - Total Tax-\% Retail Price 


\section{References}

Armingeon, K., Leimgruber, P., Beyeler, M. and Menegale, S. (2006). Comparative Political Data Set 1960-2004, Institute of Political Science, University of Berne.

Brueckner, J. K. (2003). 'Strategic interaction among governments: an overview of empirical studies', International Regional Science Review, vol. 26 (2), pp. 175-88.

Case, A. C., Hines, J. R. Jr. and Rosen, H. S. (1992). 'Budget spillovers and fiscal policy interdependence: evidence from the States', Journal of Public Economics, vol. 52, pp. 285-307.

Crawford, I., Smith, Z. and Tanner, S. (1999). 'Alcohol taxes, tax revenues and the Single European Market', Fiscal Studies, vol. 20 (3) (September), pp. 287-304.

Devereux, M.P., Lockwood, B. and Redoano, M. (2007). 'Horizontal and vertical indirect tax competition: theory and some evidence from the USA', Journal of Public Economics, vol. 91 (April), pp. 451-79.

Egger, P., Pfaffermayr, M. and Winner, H. (2005). 'Commodity taxation in a "linear world": a spatial panel approach', Regional Science and Urban Economics, vol. 35, pp. 527-41.

Evers, M., de Mooij, R.A. and Vollebergh, H.R.J. (2004). 'Tax competition under minimum rates: the case of European diesel excises', Tinbergen Institute Discussion Paper No. 04-062/3.

European Commission, Directorate General XXI Customs and Indirect Taxation. (various years). 'Excise Duty tables', 1987-2004.

HMRC (2002). 'Measuring indirect tax losses', London: HMSO.

Kanbur, R., and Keen, M. (1993). 'Jeux sans frontiers: tax competition and tax coordination when countries differ in size', American Economic Review, vol. 83, pp. 887-92.

Keen, M. (1993). 'The welfare economics of tax co-ordination in the European Community: a survey', Fiscal Studies, vol. 14, pp. 15-36.

Lockwood, B. (1993). 'Tax competition in a customs union under destination and origin principle', Journal of Public Economics, vol. 53, pp. 141-62.

Lockwood, B., and Migali, G. (2008). 'Did the single market cause competition in excise taxes? Evidence from EU Countries', Warwick Economic Research Papers, No. 847.

Nelson, M.A. (2002). 'Using excise taxes to finance state government: do neighboring state taxation policy and cross-border markers matter?', Journal of Regional Science, vol. 42, pp. 731-52.

Nielsen, S.B. (2001). 'A simple model of commodity taxation and cross-border shopping', Scandinavian Journal of Economics, vol. 103, pp. 599-623.

Ohsawa, Y. (1999). Cross-border shopping and commodity tax competition among governments, Regional Science and Urban Economics, vol. 29, pp. 33-51.

Pace, R.K. and Barry, R. (1998). 'Spatial Statistics Toolbox 1.0', Real Estate Research Institute, Louisiana State University, Baton Rouge, LA.

Pagan, A.R. and Hall, A.D. (1983). 'Diagnostic tests as residual analysis', Econometric Reviews, vol. 2, pp. 159218.

Rork, J. C. (2003).'Coveting thy neighbors' taxation', National Tax Journal, vol. 56 (4), pp. 775-87.

Schmidt, M. G. (1996). 'When parties matter: a review of the possibilities and limits of partisan influence on public policy', European Journal of Political Research, vol. 30, pp. 155-83.

Wooldridge, J.M. (2002). Econometric Analysis of Cross-Section and Panel Data, Cambridge MA: MIT Press. 